\title{
Glacier mass balances (1993-2001), Taylor Valley, McMurdo Dry Valleys, Antarctica
}

\author{
Andrew G. FOUNTAIN, ${ }^{1}$ Thomas H. NYLEN, ${ }^{1}$ Karen L. MacCLUNE, ${ }^{2 *}$ Gayle L. DANA ${ }^{3}$ \\ ${ }^{1}$ Departments of Geology and Geography, Portland State University, PO Box 751, Portland, Oregon 97207-0751, USA \\ E-mail: andrew@pdx.edu \\ ${ }^{2}$ Institute of Arctic and Alpine Research, University of Colorado, Boulder, Colorado 80309-0450, USA \\ ${ }^{3}$ Desert Research Institute, University of Nevada, Reno, Nevada 89512-1095, USA
}

\begin{abstract}
Mass balances were measured on four glaciers in Taylor Valley, Antarctica, from 1993 to 2001. We used a piecewise linear regression, which provided an objective assessment of error, to estimate the mass balance with elevation. Missing measurements were estimated from linear regressions between points and showed a significant improvement over other methods. Unlike temperate glaciers the accumulation zone of these polar glaciers accumulates mass in summer and winter and the ablation zone loses mass in both seasons. A strong spatial trend of smaller mass-balance values with distance inland $\left(r^{2}=\mathbf{0 . 8 0}\right)$ reflects a climatic gradient to warmer air temperatures, faster wind speeds and less precipitation. Annual and seasonal mass-balance values range only several tens of millimeters in magnitude and no temporal trend is evident. The glaciers of Taylor Valley, and probably the entire McMurdo Dry Valleys, are in equilibrium with the current climate, and contrast with glacier trends elsewhere on the Antarctic Peninsula and in temperate latitudes.
\end{abstract}

\section{INTRODUCTION}

The global distribution of glacier mass-balance programs is concentrated in the temperate regions (Dyurgerov and Meier, 2000), with comparatively few observations from the polar regions. Consequently, any mass-balance measurements, particularly from around Antarctica, are valuable additions for assessing global glacier change and for calculating the contribution of glaciers to sea-level rise (Dyurgerov and others, 2002). One area of particular interest is the McMurdo Dry Valleys (Fig. 1), the largest ice-free expanse on the Antarctic continent (Chinn, 1980). This region is the source of many investigations attempting to infer past glaciations and climatic events in Antarctica (e.g. Denton and others, 1989). Understanding of current massbalance processes in the dry valley climate can be used to infer past climate conditions based on geologic evidence of former glacier extent (e.g. Hall and others, 1997).

Previous measurements of glacier mass balance in the McMurdo Dry Valleys were collected in Wright Valley (Fig. 1). Bull and Carnein (1970) measured the mass balance of Meserve Glacier for 1 year from November 1965 to November 1966. A more extensive mass-balance program monitored three glaciers in Wright Valley during the 1970s (Chinn, 1980, 1985). Results showed low values of mass exchange, generally no more than about $100-200 \mathrm{~mm} \mathrm{w.e.}^{-1}$, typical of cold polar environments.

In 1993 a long-term ecological research project was initiated in Taylor Valley, Antarctica (Fig. 1), to study the physical and chemical controls on the ecosystem in that polar desert (Fountain and others, 1998; BioScience, 1999). The only major source of water to the ephemeral streams and ice-covered lakes in the valleys is from glacial melt (Chinn, 1981). To understand the variations in stream-flow, a study of the glaciers was undertaken and glacier mass balances were measured. The purpose of this paper is to

*Present address: S.S. Papadopulos \& Associates, Inc., 1877 Broadway, Suite 703, Boulder, Colorado 80302-5245, USA. report the results of our mass-balance program. Because of the low values of mass exchange, we altered the typical approach to mass-balance measurements to include an improved estimate of measurement error and the resulting uncertainty in the mass-balance calculations.

\section{STUDY SITE}

Taylor Valley (Fig. 2) trends northeast to southwest, extending about $35 \mathrm{~km}$ from McMurdo Sound to the point

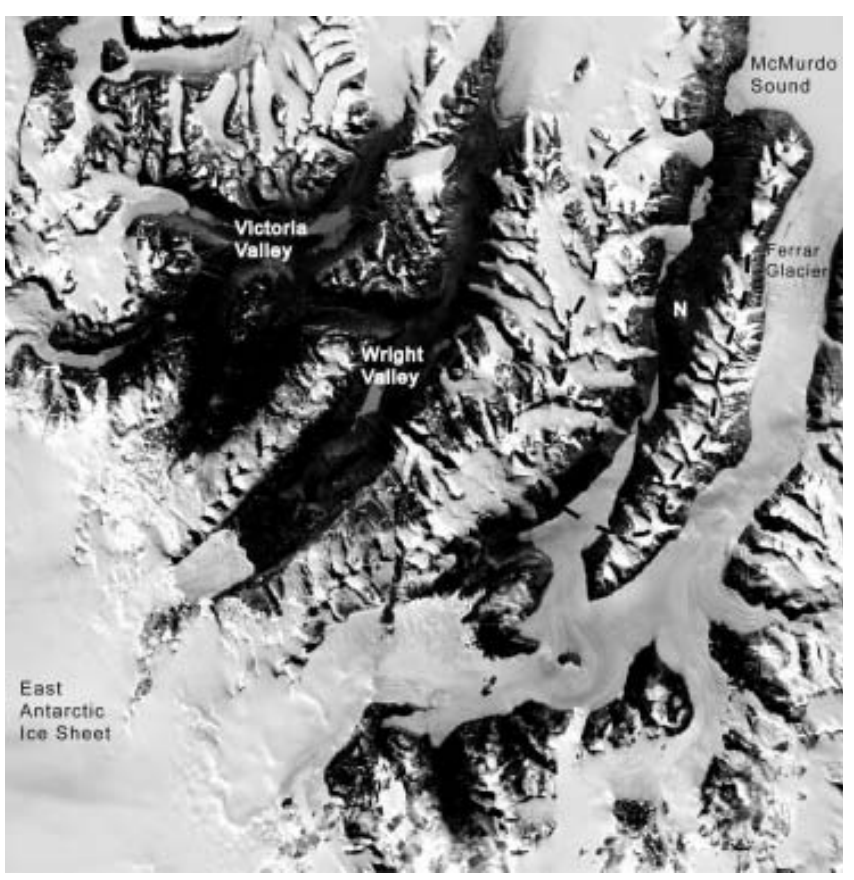

Fig. 1. Landsat-7 satellite image of the McMurdo Dry Valleys, 19 December 1999. The dashed box surrounds Taylor Valley and the $\mathrm{N}$ indicates the position of the Nussbaum Riegel, which is sunlit just to the left. 


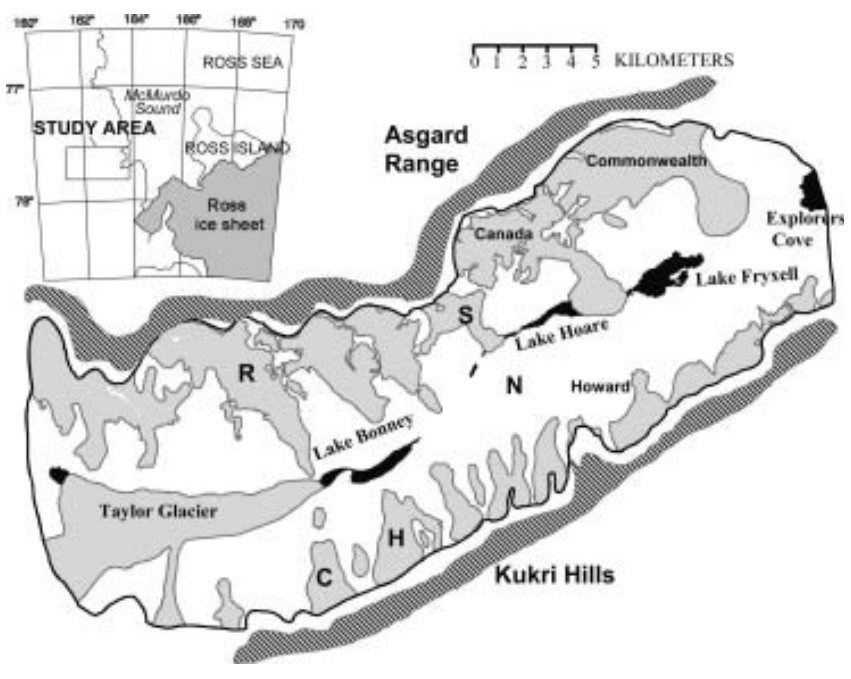

Fig. 2. Map of Taylor Valley. The black shading shows the perennially ice-covered lakes. The grey shading shows the glaciers. The named glaciers are those for which we have a network of massbalance stakes. Other glaciers are shown by initials: R: Rhone Glacier, C: Caulkin Glacier, H: Hughes Glacier, S: Suess Glacier. For the latter two glaciers we maintain just two ablation stakes on each. Cross-hatching indicates the crests of the Kukri Hills and Asgard Range. $\mathrm{N}$ is the location of the Nussbaum Riege.

where Taylor Glacier enters the valley from the East Antarctic ice sheet. The valley is bounded on the north by the Asgard Range and on the south by the Kukri Hills. Taylor Valley is divided by the Nussbaum Riegel, a $700 \mathrm{~m}$ hill near the center of the valley (Fig. 1), into two enclosed drainage basins, Lake Bonney and Lake Fryxell. A smaller third basin is formed by Canada Glacier, which dams Lake Hoare, preventing its flow to Lake Fryxell.

Elevations in the valley range from sea level to over $2000 \mathrm{~m}$ in the Asgard Range. The glaciers are polar alpine with the exception of Taylor Glacier, which is an outlet glacier of the East Antarctic ice sheet. Together, these glaciers cover roughly $35 \%$ of the valley. Two glaciers terminate in the lakes: Taylor Glacier terminates in Lake Bonney, and the western lobe of Canada Glacier terminates in Lake Hoare. Numerous glaciers reach the valley bottom where summer melt creates ephemeral streams that flow to perennially ice-covered lakes.

The climate of Taylor Valley is distinctly polar. Sunlight varies between 4 months of darkness in winter and 4 months of direct sunlight in summer (Nylen and others, 2004). Average annual air temperatures in the valley bottom vary from -17.7 to $-20.2^{\circ} \mathrm{C}$, depending on location (Doran and others, $2002 \mathrm{~b}$ ), and extremes range from $-60^{\circ} \mathrm{C}$ in winter to $+10^{\circ} \mathrm{C}$ in summer. Winds are greatest in winter, when katabatic winds are most frequent, typically exceeding $20 \mathrm{~m} \mathrm{~s}^{-1}$ and commonly increasing winter air temperatures by $15^{\circ} \mathrm{C}$ in a few hours (Nylen and others, 2004). The average annual wind speed is about $3 \mathrm{~m} \mathrm{~s}^{-1}$ (Clow and others, 1988; Doran and others, 2002b). Measurements at Vanda Station in neighboring Wright Valley indicate that precipitation falls as snow, except in rare circumstances, and averages about $6 \mathrm{~mm}$ w.e. $\mathrm{a}^{-1}$ (Bromley, 1985). Taylor Valley climate is spatially variable, with warmer temperatures, lower humidity and greater wind speeds up-valley away from the coast (Fountain and others, 1999; Doran and others, 2002b). Over the past 14 years (1986-2000), the

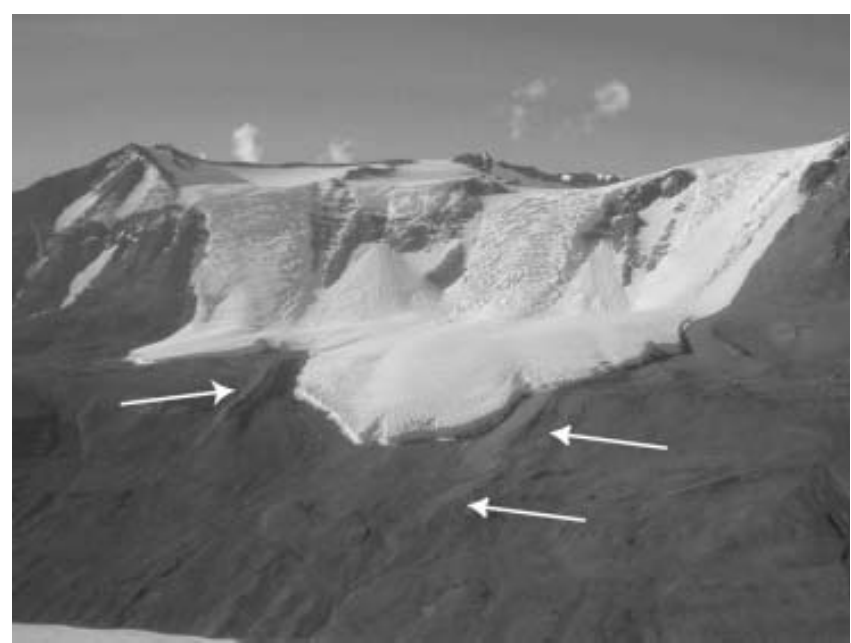

Fig. 3. Hughes Glacier. Note the vertical cliffs that define the glacier margin. These are about $20 \mathrm{~m}$ high. Arrows indicate the terminal moraines.

climate of the McMurdo Dry Valleys has cooled at a rate of $-0.7^{\circ} \mathrm{C}$ per decade (Doran and others, 2002a).

Alpine glaciers in Taylor Valley are apparently quite stable. Based on K/Ar dating of emplacement and postemplacement modifications of cinder cones in the valley, alpine glaciers have not advanced more than a few hundred meters from their present position since the Pliocene, about $3.5 \times 10^{6}$ years BP (Wilch and others, 1993). The current glacier extents may be in their most advanced position compared with the past 12000-14000years BP (Denton and others, 1989). In historic times, photographs from the British Antarctic Expedition of 1911 (Taylor, 1916) were compared with photographs taken in 1962 of Taylor and Canada Glaciers (Péwé and Church, 1962). Although the camera perspective was poor, no change was observed and certainly no large change occurred similar to that in the temperate regions since the Little Ice Age (Grove, 2001). Fountain and others (2004) compared photographs taken in the 1970s with photos taken in the 1990s and found that Canada Glacier advanced only a few meters. In addition, the glacier had thinned near the terminus during the same period. Measurements from fixed cairns to the glacier front over the past 20 years showed that roughly half of the glaciers in the dry valleys, exclusive of Taylor Valley, advanced less than $10 \mathrm{~m}$ and the other glaciers retreated less than $10 \mathrm{~m}$ (Chinn, 1998).

\section{CHARACTERISTICS OF GLACIERS IN TAYLOR VALLEY}

The glaciers of Taylor Valley are remarkably clean of debris, and medial moraines are composed of a sparse scattering of rocks rather than the rocky mantling associated with temperate glaciers (Taylor, 1916). Crevasses are not particularly common, except in icefalls. In ablation zones, crevasses trap meltwater, which refreezes, forming smooth glacier surfaces. The larger glaciers extend to the valley floor where they spread out forming a fan-like shape (Fig. 3). Vertical cliffs, about $20 \mathrm{~m}$ high, typically form the terminal margin of the glaciers. At the base of the cliffs, an ice apron forms from the calved blocks of ice that are welded together during cycles of melting and refreezing. These aprons range 

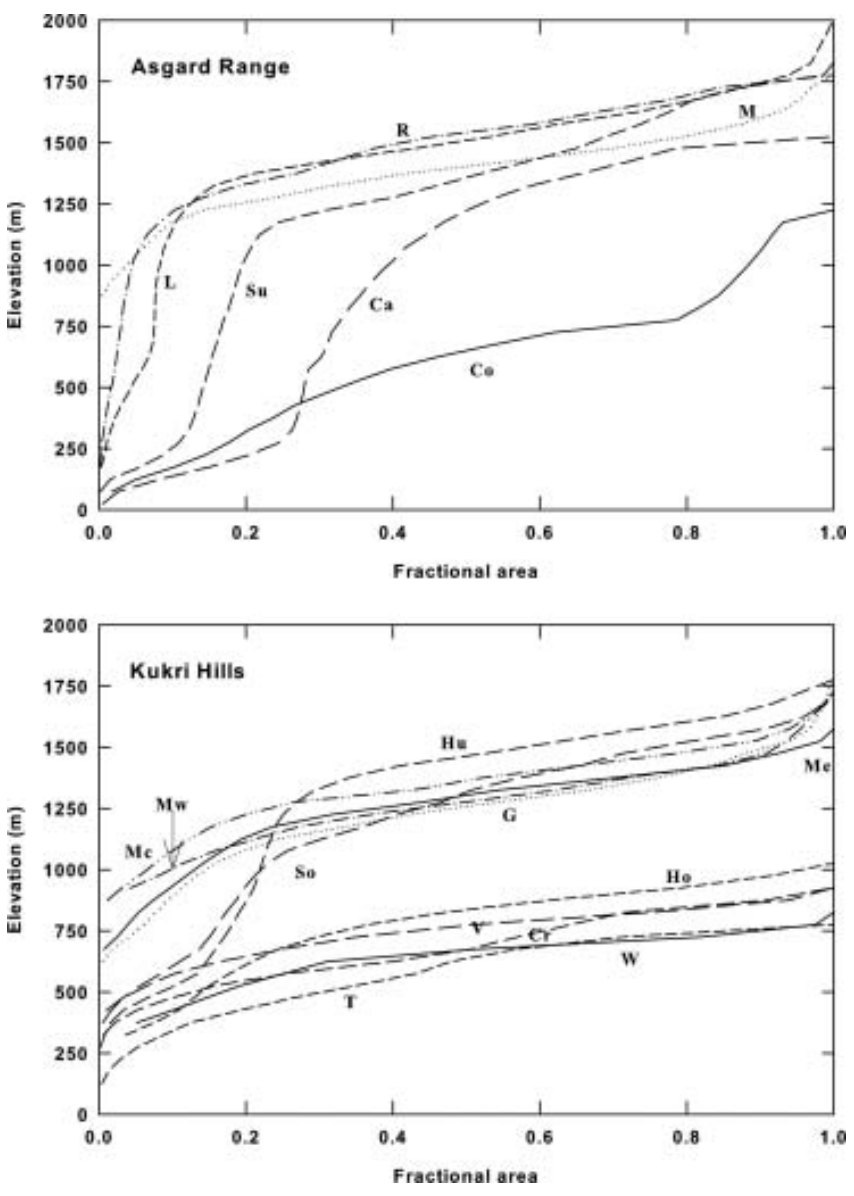

Fig. 4. Area-altitude distributions of the glaciers in Taylor Valley, grouped whether the glaciers are flowing from the Asgard Range or the Kukri Hills. The altitude is plotted in intervals of $50 \mathrm{~m}$. The area is the summation of the fractional area relative to total area for each glacier. Asgard Range: R: Rhone, L: LaCroix, M: Matterhorn, Su: Suess, Ca: Canada, Co: Commonwealth. Kukri Hills: Mc: Marr central, Mw: Marr west, So: Sollas, Hu: Hughes, G: Goldman, Me: Marr east, T: Taylor (in Taylor Valley), Ho: Howard, V: Von Guerard, Cr: Crescent, W: Wales.

up to several meters high and approximately $10 \mathrm{~m}$ wide (Taylor, 1916; Chinn, 1991).

The spatial characteristics of the Taylor Valley glaciers are derived from 1:50000 US Geological Survey topographic maps, which are based on aerial photographs acquired in 1970. Although these maps are more than 30 years out of date, the glaciers have changed little (Fountain and others, 2004) and the maps are sufficient for characterizing glacial topography. The glaciers of Taylor Valley generally face northwest or southeast. The northeast aspect of Taylor Glacier is different from the others because it flows into the valley between the ranges. Six glaciers flow from the Asgard Range and average $28 \mathrm{~km}^{2}$ in area with a total combined area close to $168 \mathrm{~km}^{2}$; ten glaciers flow from the Kukri Hills and average $6.5 \mathrm{~km}^{2}$ in area with a total combined area of $65 \mathrm{~km}^{2}$. The portion of Taylor Glacier in Taylor Valley is about $84.4 \mathrm{~km}^{2}$.

The area-altitude distribution of the glaciers in the Kukri Hills cluster into two groups based on their maximum elevation limit (Fig. 4). One group (Wales, Unnamed, Crescent and Howard glaciers) reaches elevations up to $1000 \mathrm{~m}$ and is located to the east of the Nussbaum Riegel. The other group (Goldman, Marr east, Marr central, Marr

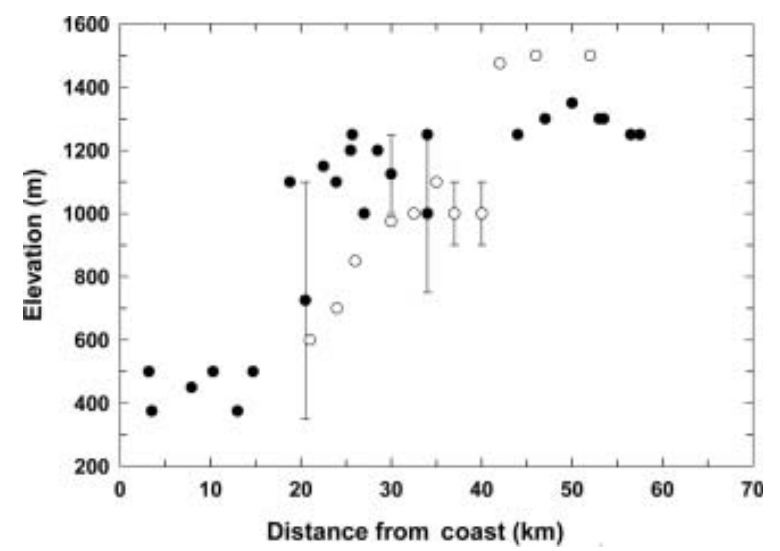

Fig. 5. ELA as a function of distance from the coast for Taylor Valley (closed circles) and Wright Valley (open circles) (adapted from Fountain and others, 1999). The error bar indicates the range of uncertainty in determining the altitude.

west, Sollas, Hughes, and Caulkin) reaches elevations up to $1800 \mathrm{~m}$ and is located west of the riegel. The fraction of glacier area at low elevations generally decreases with distance from the coast. Similarly, maximum glacier elevation in the Asgard Range increases with distance from the coast as the fraction of glacier area at low elevation decreases. The trend of maximum glacier elevation follows that of the mountain ranges, which also increases from the coast. The trend of decreasing glacier area at low elevations results from higher glacier equilibrium-line altitudes (ELAs) due to the warming and drying climate gradient.

We estimated the ELA for all glaciers in Taylor Valley (Fig. 5) based on the curvature of the mapped surface contours on each glacier (Leonard and Fountain, 2003). The ELAs of the glaciers in the adjacent Wright Valley are included for comparison. The data show a rise in ELA of $700 \mathrm{~m}$ in Taylor Valley over a distance of $10 \mathrm{~km}$, yielding an astonishing gradient of $70 \mathrm{~m} \mathrm{~km}^{-1}$ (Fountain and others, 1999). For comparison, the rise in the mean elevation (a proxy for the ELA) of glaciers in the North Cascade Mountains, USA, yields a gradient of $3 \mathrm{~m} \mathrm{~km}^{-1}$ (Post and others, 1971). The abrupt rise in ELA within Taylor Valley coincides with the position of the Nussbaum Riegel, which not only physically divides Taylor Valley into two parts but also creates two different climatic regimes (Fountain and others, 1999). Precipitation-bearing storms usually flow upvalley from the coast; the Nussbaum Riegel blocks the passage of smaller storms, reducing snowfall in the western part of the valley. At the same time, greater winds and warmer air temperatures west of the riegel increase sublimation. The increasing ELA with distance from the ocean explains the trend of decreasing fraction of glacier area at low elevations, despite higher accumulation zones.

Mass gain of dry valley glaciers is dominated by direct snowfall and perhaps wind redistribution of snow. Contributions from snow avalanches have not been observed or inferred from snow deposits. A few small glaciers are formed along cliff bottoms from the accumulation of ice blocks avalanching from glaciers above. The blocks partially melt and refreeze, forming a conglomerate-like ice assemblage. One such example is the lower Caulkin Glacier, adjacent to Taylor Glacier. Glacier ablation is dominated by sublimation at all elevations; melt loss only occurs in the lowermost elevations of the ablation zone. During our study period, we 

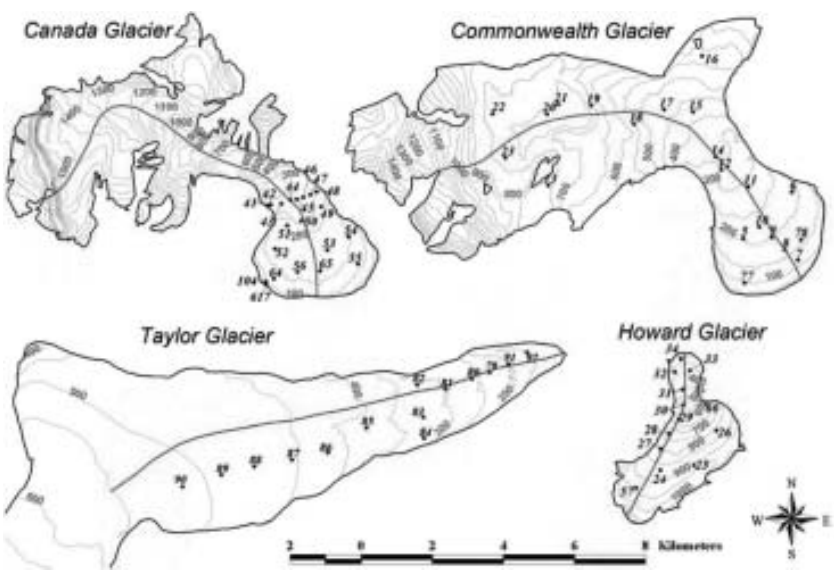

Fig. 6. Locations of mass-balance measurements on the four glaciers studied. Each bamboo pole is designated with a point and its unique number. The line on each glacier shows the glacial crosssection location depicted in Figure 11. Contour interval is $50 \mathrm{~m}$.

rarely observed snowmelt. However, paper-thin ice layers are relatively common in snow pits dug in the accumulation zone. These layers may be melt-surface crusts that are buried by subsequent snow accumulation or internal melt layers (Brandt and Warren, 1993; Liston and others, 1999). Dry snow is always found at depth and we infer that no meltwater is lost from the accumulation zone. In the ablation zone, sublimation accounts for $40-80 \%$ of the summer mass loss (Lewis and others, 1998), corroborating Bull and Carnein's (1970) estimate of 58\%. In winter, when direct solar radiation is absent and air temperatures are well below freezing, only sublimation occurs. Ice calves from the cliffs along the glacier's edge (Fountain and others, 1998) and it appears to be an exfoliation-like process. The cliff face fails along a segment typically approximately tens of meters long with blocks roughly $0.5 \mathrm{~m}$ thick. Bull and Carnein (1970) estimate that calving represents about $1.5 \%$ of the ablation from Meserve Glacier in Wright Valley.

\section{MASS-BALANCE MEASUREMENTS Field methods}

Four glaciers were selected for mass-balance measurements according to their accessibility, importance to stream-flow, and valley position (north/south-facing, distance from the coast). Measurements were made over the entire surface of two glaciers. Commonwealth Glacier flows from the Asgard Range on the north side of the valley and is the closest to the coast of all measured glaciers. Several steep (30-46 $)$ tributaries flowing to the head of the glacier are not measured. The patchy exposures of bedrock within the tributaries and relatively little snow cover on the ice surface indicate little contribution to the glacier mass balance. A branch of Commonwealth Glacier connects to Wilson Piedmont Glacier; however, the glaciers are dynamically separated by a flow divide. The second glacier is Howard Glacier, which flows from the Kukri Hills on the south side of the valley, located about one-third the distance up-valley.

The two other measured glaciers are Canada and Taylor. For both glaciers, measurements are limited to the ablation zone for assessing meltwater runoff to the streams and lakes. Canada Glacier flows from the Asgard Range and is located across the valley from Howard Glacier. Taylor Glacier, as previously mentioned, lies at the head of Taylor Valley and is an outlet glacier from the East Antarctic ice sheet. The equilibrium line of the glacier is located at roughly 2080 m a.s.l. (Robinson, 1984) and about $65 \mathrm{~km}$ from where the glacier enters Taylor Valley. Our measurements are limited to the lower $11 \mathrm{~km}$. In addition, we make two measurements each on Suess and Hughes Glaciers to test our interpolation of mass-balance values between Canada and Taylor and between Howard and Taylor, respectively. However, these data are not included in this paper.

Our approach to assessing glacier mass balance follows traditional methods (Andreassen, 1999; Holmlund and Jansson, 1999) with some adaptations to dry valley conditions. On each glacier, a network of bamboo poles was drilled (Fig. 6). Because the rates of accumulation and ablation are low, the same poles are used for about 5 years before being replaced. The mass change per unit area at each pole is determined from the length change between the pole top and the glacier surface since the previous observation and from the density of the surface. Measurements were made twice a year to define the summer and winter mass balance: late October/early November (end of winter) and late January (end of summer). Glaciologically speaking, we define winter as February-October and summer as November-January. In some years, we made measurements in mid- to late December (mid-summer) to quantify mass changes in early vs late summer. Because of the logistical constraints of Antarctic fieldwork, our measurements are based on the fixed-date system (Meier and Tangborn, 1965) and therefore are annual balances. We calculate annual balances from the sum of the seasonal balances between each austral spring, matching the Northern Hemisphere balance year that starts on 1 October. Therefore the annual balance for the year 2000 is the sum of the previous winter (February-October 2000) and the previous summer (November 1999-January 2000).

Pole lengths were initially measured to the nearest centimeter, but results showed that length changes typically did not exceed about $100 \mathrm{~mm}$. In following years, measurements were made to the nearest millimeter. The ice surfaces are typically rough around each pole, where ablation wells of a few centimeters in depth form. A wooden plate, $10 \mathrm{~cm}$ in radius, was placed on the glacier surface around the pole to average local roughness variations. The length of the pole to the board surface was measured along four different sides of the pole to account for tilt. In snow, the depth of the board footprint was also measured. For snow-covered ice, snow depth measurements were made. Four depth measurements were made around the perimeter of the board and another four about $20 \mathrm{~cm}$ from the pole. These multiple measurements provide a statistical measure of the accuracy of pole length and snow depth.

The ice density was assumed to be constant at $0.9 \mathrm{~g} \mathrm{~cm}^{-3}$ and the snow density was measured at each pole. A snow pit was dug to a depth equal to the snow accumulated over the past year to ensure we measured the full depth of snow accumulated since the previous observation. After a quick stratigraphic analysis of the snow in each pit, the density of each layer was measured using a $100 \mathrm{~cm}^{-3}$ sampler and a spring scale. The mass was repeatable within $\pm 0.5 \mathrm{~g}$. However, because we do not take replicate measurements of the density, no error is assigned to those values.

For the terminus cliffs, ablation was measured in two ways. To account for sublimation/melting, poles were drilled 


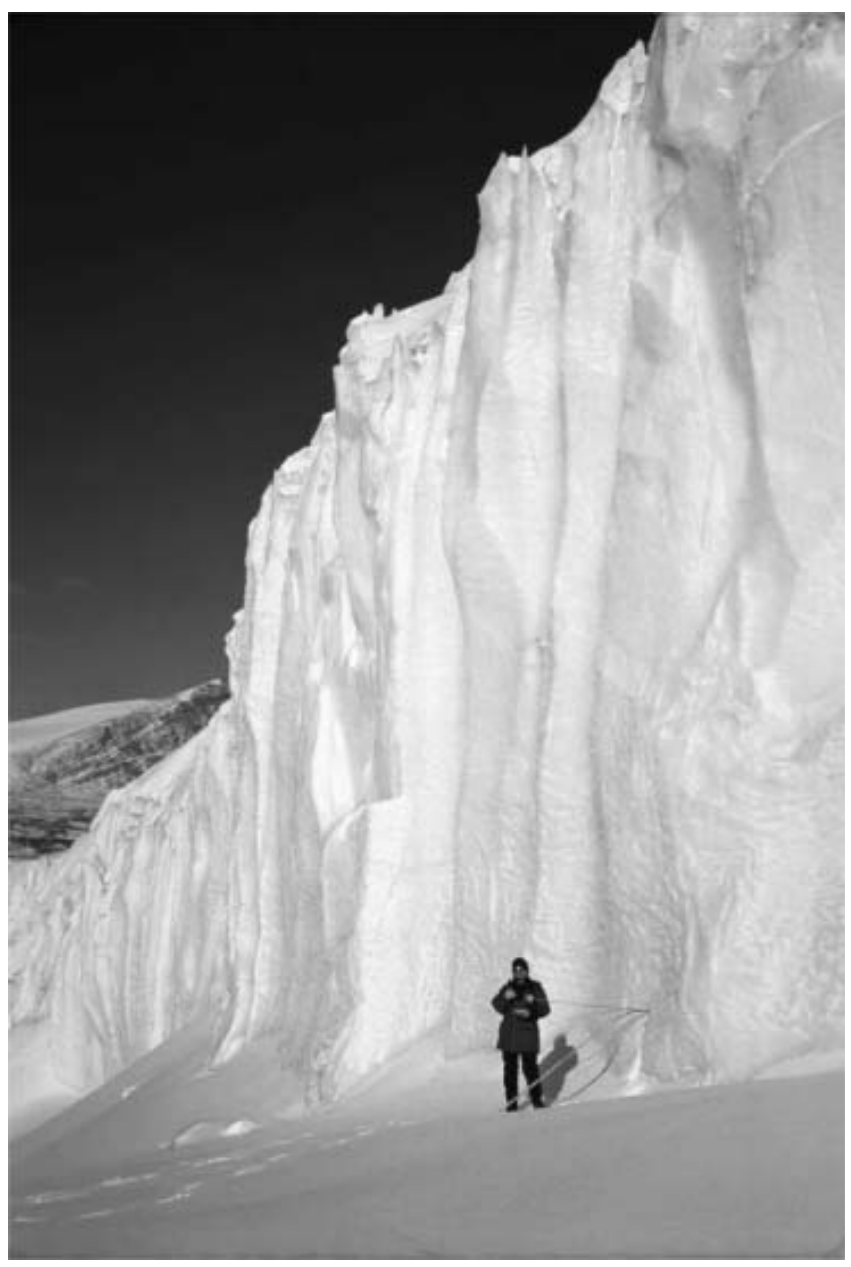

Fig. 7. Karen MacClune measuring a bamboo pole in an ice cliff at Commonwealth Glacier.

horizontally into the cliff face 1-2 $\mathrm{m}$ above the apron where they can be reached easily. These poles were usually supported by vertical poles drilled into the ice apron at the bottom of the cliff (Fig. 7). Measurements of the poles followed the same procedure described above. For calving, there is no direct way to measure the volume lost. We estimated the magnitude of calving by taking photos of the entire ice cliff from several different viewpoints around the glacier front. Both the cliff photos and pole measurements coincided with the surface mass-balance measurements. Photo comparisons revealed locations and dimensions of calving events. The thickness of the calved blocks was measured occasionally in the field, and typically averaged about $0.5 \mathrm{~m}$. The estimated volume loss was the product of calved area and thickness $(0.5 \mathrm{~m})$. After several years of making cliff measurements we abandoned them due to safety issues and time-consuming maintenance for little return in data. Ultimately, the results showed mass loss from the ice cliffs is small compared with losses elsewhere on the glacier. We used average values from the measurement years to estimate cliff losses during the subsequent years.

\section{Field results}

\section{Average surface mass-balance values}

Mass-balance measurements were collected from November 1993 to November 2001. Every pole on the sub-horizontal surface (as opposed to the cliff wall) was measured except in
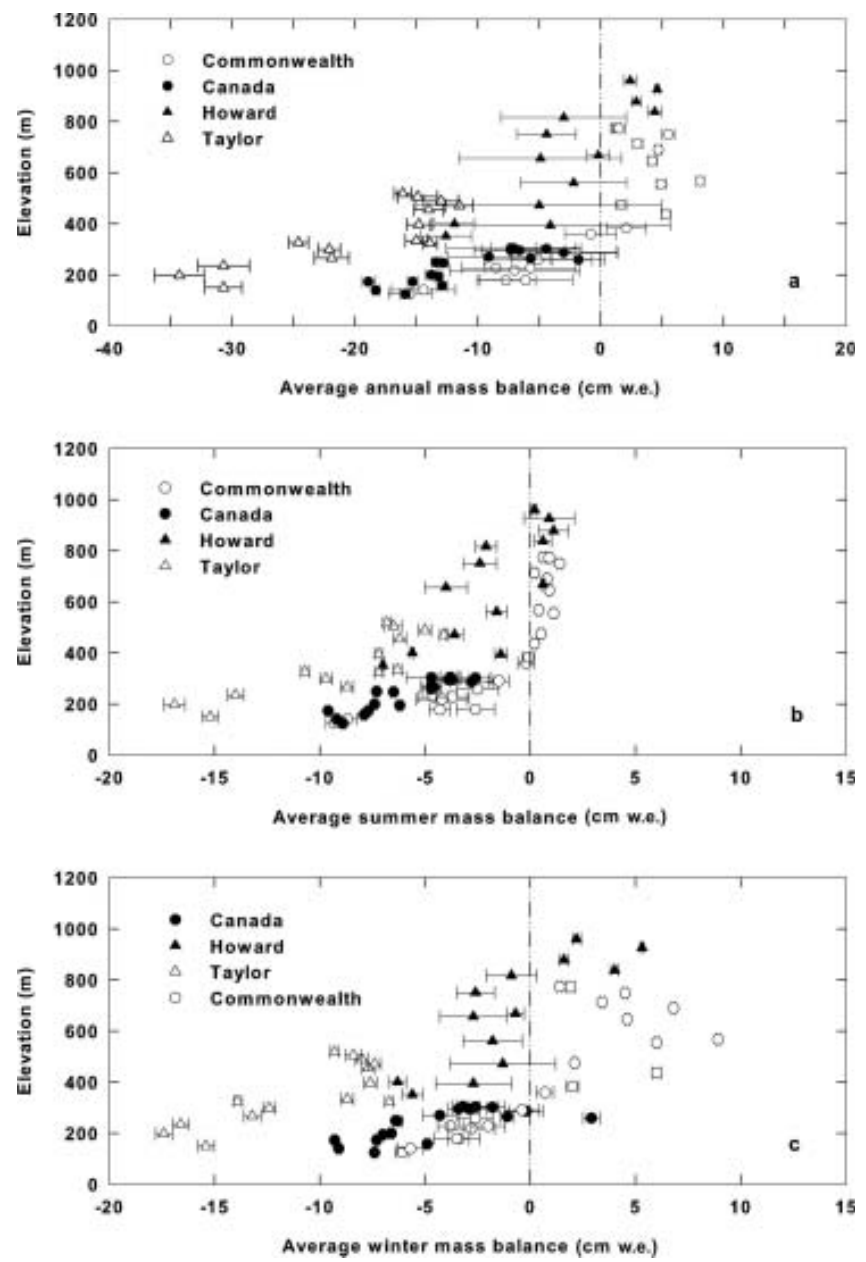

Fig. 8. Average mass balance with elevation for four glaciers in Taylor Valley, Antarctica: (a) annual; (b) summer; (c) winter. The scale is different for the annual balance from the two seasonal balances. Note the decreasing balance at constant elevation with distance from the coast. Commonwealth Glacier is closest to the coast, followed by Howard and Canada, with Taylor Glacier furthest from the coast. Howard and Canada glaciers are about the same distance from the coast but the terminus of Howard is much higher.

November 1997 when only those poles in the ablation zone were measured. The point values of annual mass balance ranged from +110 to $-370 \mathrm{~mm}$ w.e. with uncertainty of about $3 \mathrm{~mm}$. The smallest uncertainty $(2-4 \%)$ was in the accumulation zone, where the snow typically formed a flat surface around the pole and the wooden plate was nearly perpendicular to the pole. In the ablation zone, uncertainty was larger (approximately $10 \%$ ) due to the rougher ice surface. One exception is Taylor Glacier which had smooth ice surfaces and the uncertainty was similar to those in the accumulation zone of other glaciers. The largest uncertainty (approximately 20-40\%) occurred on snow-covered ice because of the point measurements through the snow to the rough ice surface below.

The annual mass balance increases with elevation, like most glaciers (Fig. 8). However, the mass balance at a constant elevation decreases with distance from the coast. Seasonal mass-balance values exhibit the same overall spatial trend as the annual values. However, differences between glaciers are more pronounced in winter than summer for three reasons. First, more snow accumulates in the 9 months of winter than in the 3 months of summer, and 
the glaciers nearer the coast receive greater snowfall. Second, winter ablation increases up-valley because katabatic winds are more frequent away from the coast (Doran and others, 2002b; Nylen and others, 2004). Third, in summer, less precipitation and less frequent katabatic winds reduce the differences in ablation among glaciers.

The accumulation zones of Commonwealth and Howard Glaciers gain mass during both seasons as the ablation zone loses mass in both seasons. Although departures from this general pattern occur, it underscores one of the distinguishing characteristics between the polar alpine glaciers of the dry valleys and temperate alpine glaciers: the snowline does not shift to lower elevations in winter or to higher elevations in summer.

\section{Missing data}

The poles in the accumulation zones of Commonwealth and Howard Glaciers were not measured in the spring (November) of 1997 due to logistical constraints. The mass-balance time series was completed by estimating the summer balance from November 1997 to January 1998 and subtracting it from the balance between January 1997 and January 1998 to estimate the winter balance from January to November 1997. Two methods of estimation are evaluated: the linear balance model of Lliboutry (1974) and a linear regression between measured poles.

Lliboutry (1974) stated that the mass balance at any individual pole is a linear combination of a variable related to the pole's position in space and in time,

$$
b_{s, t}=\alpha_{s}+\beta_{t}+\varepsilon_{s, t},
$$

where $b_{s, t}$ is the balance at a location, $s$, on the glacier at time $t$. The mass-balance variable that depends on location alone is $\alpha_{s}$; the variable that depends on time is $\beta_{t}$; and $\epsilon_{s, t}$ is the random error associated with the estimate. The values of $\alpha_{s}, \beta_{t}$, and $\epsilon_{s, t}$ are subject to the condition that,

$$
0=\sum_{s=1}^{n} \alpha_{s} ; \quad 0=\sum_{t=1}^{m} \beta_{t} ; \quad \text { and } \quad 0=\sum_{s=1}^{n} \sum_{t=1}^{m} \varepsilon_{s, t},
$$

where $n$ is the total number of measurement points on the glacier and $m$ is the total number of years. Equations (1) and (2) were applied to a matrix of pole values on each glacier, where $s$ represents each pole and $t$ is defined for each season. For Commonwealth Glacier the matrix was 8 (years) by 21 (poles) with 16 missing values. In 1995, 4 poles were added to the network on Commonwealth Glacier, and to complete the dataset their values were estimated for 1994. In 1997, 12 poles in the accumulation zone were not measured. For Howard Glacier the matrix was 8 (years) by 13 (poles) with 10 total missing values, 1 in 1993 and 9 in 1997. Canada Glacier is missing two measurements in 1993. No data were missing from Taylor Glacier.

Equations (1) and (2) were solved in two ways. First, they were applied directly and the missing values were calculated. Second, the method was iterated, replacing the missing values with the estimated quantities, and the entire matrix including estimated values was used to calculate the spatial and temporal variables. Iterations continued until the estimates of the missing values changed by less than $0.5 \mathrm{~mm}$ w.e., a factor of two smaller than the measurement resolution. Solutions converged after about 10 iterations. Tests using data from Commonwealth Glacier showed that the root-mean-square error (rmse) between the iterated and non-iterated values was only $0.9 \mathrm{~mm}$ w.e. Consequently, the iteration procedure was not implemented. The rmse between measured and estimated mass-balance values for Commonwealth and Howard Glaciers is 20 and $17 \mathrm{~mm}$ w.e., respectively. This calculated error is a minimum because it is based on the same measured poles used to calculate the difference. An independent check was made using a split sample of the data from Howard Glacier. Seven known values in the same year were withheld (simulating the data structure of the actual situation) and estimated. The rmse for the poles withdrawn was $24 \mathrm{~mm}$ w.e., larger than that for the estimated error.

For the linear regressions method, a correlation matrix was first calculated between all poles, and the best correlated poles were used to estimate the missing values. For Commonwealth Glacier the minimum correlation was 0.73 , with the majority above 0.9 . For Howard Glacier the mass-balance values were less well correlated: the minimum correlation was 0.62 and the majority were above 0.7 . Three different poles in the ablation zone of each glacier were used to predict the missing values of the rest. Results showed that for Commonwealth and Howard Glaciers, the rmse between measured and predicted values was quite low: 7.7 and $7.8 \mathrm{~mm}$ w.e., respectively. Split sample tests showed that regressions, based on 5 years of data, predicted the sixth year of data with a rmse of 11 and $14 \mathrm{~mm}$ w.e. for Commonwealth and Howard Glaciers, respectively. The regression method improved the rmse over the linear balance model by $10 \mathrm{~mm}$ w.e. for Howard Glacier and represents an error reduction of about $50 \%$. Therefore, the linear regression method was applied to estimate all the missing values in the records. The error assigned to each estimated value is onehalf of the $95 \%$ prediction intervals for each estimate.

\section{Cliff mass balance}

The terminus cliffs lose mass year-round due to sublimation/ melting and calving of ice blocks. Some of the melt and ice blocks form an ice apron at the base of the cliffs, which then melts and sublimates. Annual values of sublimation/melt from the cliffs ranged from 67 to $729 \mathrm{~mm}$ w.e. These values are probably greater than on higher parts of the cliff where the ice is further from the warm valley floors in summer. At least twice as much sublimation/melt occurs in summer compared with winter. We had problems maintaining the cliff poles due to calving events, resulting in a dataset with many gaps, an experience similar to Bull and Carnein (1970). Replacement poles could not reoccupy the same locations due to the calved ice blocks, and new poles were installed as close as possible, typically within $100 \mathrm{~m}$. Differences in aspect and local topographic characteristics preclude direct comparisons between measurements of old and new poles. No large spatial patterns of ablation around the glacier margin emerged, indicating that local influences dominate ablation processes. The difficulty in maintaining the poles leads to a dataset inadequate for specifying yearly cliff balance for each glacier. We attempted to estimate seasonal cliff sublimation/melt from measurements of surface poles, but no relation existed between the two sets of measurements, probably due to differences in snow accumulation between the glacier surface and the cliff face. We assume a constant value of seasonal melt/sublimation of the cliff face for all glaciers, based on measurements collected at Canada Glacier. Summer values average $230 \pm 70 \mathrm{~mm}$ w.e. and winter values average $110 \pm 60 \mathrm{~mm}$ w.e. These values 
Table 1. The cliff ablation volume (w.e.) for each of the four glaciers from November 1994 to November 1995

\begin{tabular}{|c|c|c|c|c|}
\hline & Commonwealth & Canada & Howard & Taylor \\
\hline Calving ablation & $\begin{array}{r}0: 350 \\
29: 200 \\
67: 250 \\
31: 200\end{array}$ & $\begin{array}{r}39: 100 \\
69: 160 \\
62: 120 \\
92: 200 \\
7: 220\end{array}$ & $\begin{array}{r}0: 250 \\
15: 250 \\
0: 150 \\
7: 220\end{array}$ & $\begin{array}{r}42: 200 \\
21: 70\end{array}$ \\
\hline Weighted average $(\mathrm{mm})$ & 29 & 53 & 6 & 37 \\
\hline Calving perimeter (m) & 5600 & 6900 & 1500 & 4000 \\
\hline Total calving volume $\left(\mathrm{m}^{3}\right)$ & 3220 & 7300 & 182 & 2924 \\
\hline Summer volume $\left(\mathrm{m}^{3}\right)$ & 805 & 1825 & 46 & 731 \\
\hline Error $\left(\mathrm{m}^{3}\right)$ & 403 & 913 & 23 & 366 \\
\hline Winter volume $\left(\mathrm{m}^{3}\right)$ & 2415 & 5475 & 137 & 2193 \\
\hline Error $\left(\mathrm{m}^{3}\right)$ & 1208 & 2738 & 68 & 1097 \\
\hline \multicolumn{5}{|l|}{ Sublimation/melt ablation } \\
\hline Summer (mm) & 230 & 230 & 230 & 230 \\
\hline Winter $(\mathrm{mm})$ & 110 & 110 & 110 & 110 \\
\hline Perimeter $(\mathrm{m})$ & 7800 & 8760 & 2170 & 18039 \\
\hline Summer volume $\left(\mathrm{m}^{3}\right)$ & 35880 & 40296 & 9982 & 82979 \\
\hline Error $\left(\mathrm{m}^{3}\right)$ & 10920 & 12264 & 3038 & 25255 \\
\hline Winter volume $\left(\mathrm{m}^{3}\right)$ & 17160 & 19272 & 4774 & 39686 \\
\hline Error $\left(\mathrm{m}^{3}\right)$ & 9360 & 10512 & 2604 & 21647 \\
\hline \multicolumn{5}{|l|}{ Total cliff ablation } \\
\hline Total summer $\left(\mathrm{m}^{3}\right)$ & 36685 & 42121 & 10028 & 83711 \\
\hline Error $\left(m^{3}\right)$ & 10927 & 12298 & 3038 & 25257 \\
\hline Total winter $\left(\mathrm{m}^{3}\right)$ & 19575 & 24747 & 4911 & 41879 \\
\hline Error $\left(\mathrm{m}^{3}\right)$ & 9438 & 10863 & 2605 & 21675 \\
\hline
\end{tabular}

Notes: The first value is the specific calving, calving volume per unit area of cliff face $\left(\mathrm{mm}^{3} \mathrm{~mm}^{-2}\right)$, and the second value is the length of cliff face over which the specific calving applies. Errors on specific calving are assumed to be $50 \%$. A weighted average (specific calving times cliff length divided by total cliff length) is calculated and applied to the estimated perimeter over which calving occurs (Calving perimeter). Total calving volume is the product of the weighted average, calving perimeter and an estimated cliff height of $20 \mathrm{~m}$. Summer and winter volumes are estimated by partitioning the total volume according the number of months in each season (summer 3 months, winter 9 months). The seasonal sublimation/melt errors are summer $\pm 70 \mathrm{~mm}$ and winter $\pm 60 \mathrm{~mm}$. Although not shown, the errors are used in the total error estimates of glacier mass balance.

are underestimates because the poles were concentrated along the side margins of the glacier to support calculations of meltwater runoff, where shading by the valley walls limits direct solar insolation.

Calving was rarely witnessed, but we would occasionally come upon a recent event that seemed to be only a few weeks or months old. Although the photographic data do not provide any sense of seasonality in calving, it is our impression that most calving occurs during the spring and autumn months. Audible cracking and groaning is heard on the cliff faces during these months when relatively large daily temperature swings occur. The total yearly ablation due to calving varied from 6 to $53 \mathrm{~mm}$ w.e. averaged over the total area of the cliff face monitored (Table 1). The calving rates showed significant differences between glaciers. The smallest glacier, Howard, with the smallest ablation zone exhibited the smallest calving rate, and the two largest glaciers, Commonwealth and Taylor, exhibited the largest calving rates. Although this result is based only on data from one year, our anecdotal observations from other years support this notion. We did not observe any notable difference in calving rates between years, and the values in Table 1 probably represent a reasonable average rate. Calving accounts for $1-10 \%$ of the ablation on the cliffs.

The mass balance of the aprons ranged from +140 to $-819 \mathrm{~mm}$ w.e. They may gain mass in winter by snowdrifts that accumulate at the cliff base and by ice blocks from calving events. It is interesting to note that at the base of east-facing cliffs we commonly observe a grus-like accumulation of mechanically weathered ice crystals. These faces receive $5 \mathrm{~W} \mathrm{~m}^{-2}$ more solar energy (personal communication from K.J. Lewis, 1998), which increases melt along crystal boundaries and weakens the structure of the ice. Like the calved blocks, grus partially melts and refreezes, contributing mass to the apron. We assume that once the ice is lost from the cliffs it is also lost from the glacier, and we do not include the aprons in our calculations. Furthermore, aprons do not form around the entire glacier front, and apron area is small compared with cliff area and insignificant compared with total glacier area.

\section{Glacier mass balance and results}

A least-squares regression was fitted to the mass-balance data with altitude to calculate the mass balance of the subhorizontal surface of the glacier (as opposed to the cliff walls). This method was chosen instead of the traditional mapping method where contours of equal mass balance are hand-drawn on the glacier to calculate an objective estimate of the error. Previous work showed that regression equations accurately reproduce the values estimated from contouring a dense field of measurements, even when the regression is based on a subset of measurements (Fountain and Vecchia, 1999). In most instances we applied a piecewise linear equation of two segments, one for the accumulation zone 

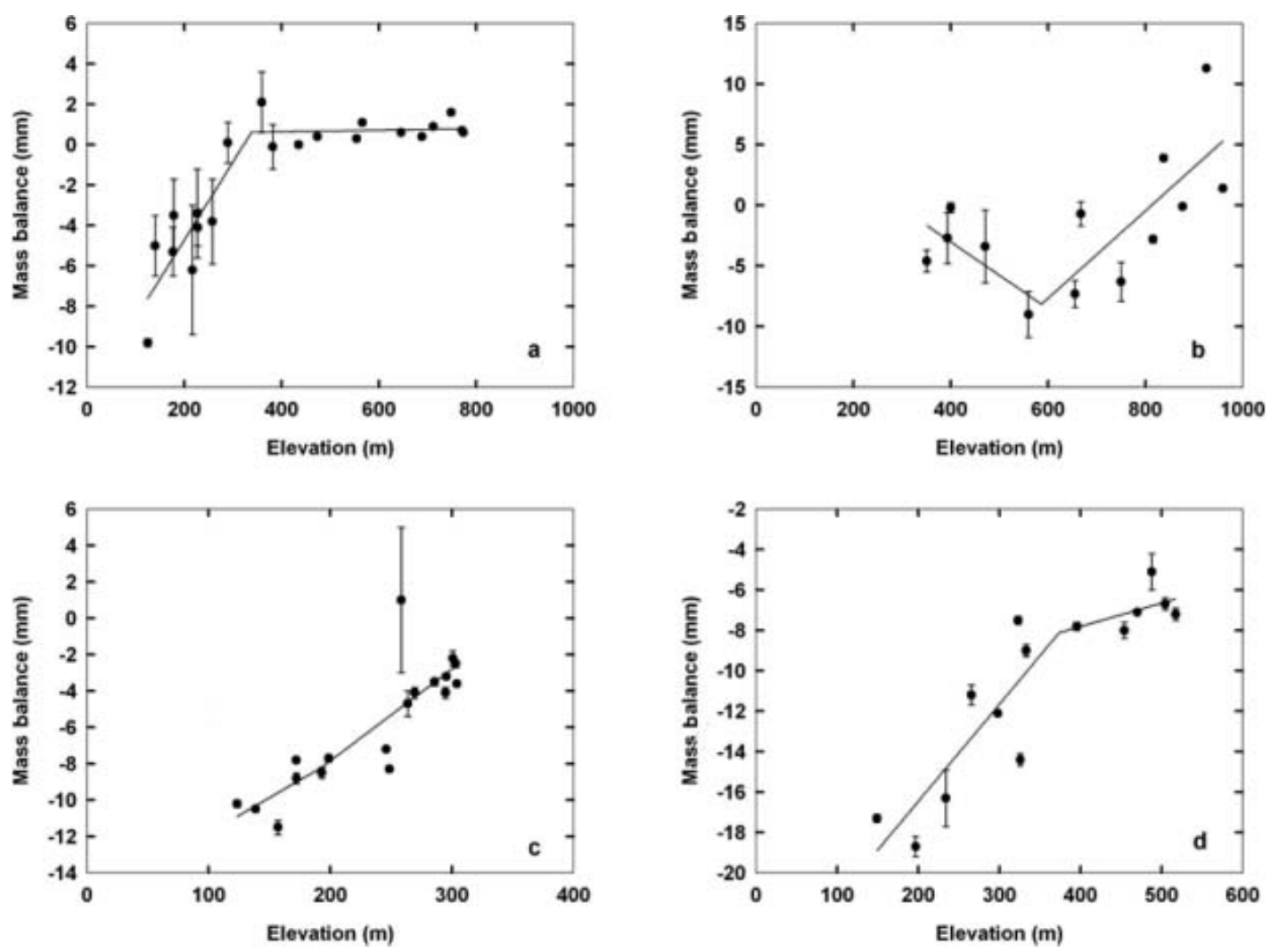

Fig. 9. Examples of fitted piecewise linear equations of mass balance vs elevation. Measured values are points with error bars indicating the standard deviation about each point. (a) Commonwealth Glacier, summer 1995/96; (b) Howard Glacier, winter 1998; (c) Canada Glacier (ablation zone), winter 1999; and (d) Taylor Glacier (ablation zone), summer 1997/98.

and one for the ablation zone. The hinge point between the two segments was calculated automatically. In several cases, a different equation was used (e.g. third-order polynomial, logistic equation) to improve the fit. These cases were limited to Taylor and Canada Glaciers where data only exist for the ablation zone. Typical results for each glacier are shown in Figure 9.

The mass balance of the sub-horizontal surface was determined by

$$
\bar{b}_{i}=\frac{1}{A} \int_{A} b_{i} \mathrm{~d} A,
$$

where $\bar{b}$ is the mass balance averaged over the glacier in water equivalent, $i$ is for summer or winter, $A$ is the area of the glacier, and $b$ is the point value of mass balance. This equation is approximated by,

$$
\bar{b}_{i}=\frac{1}{A} \sum_{\min z}^{\max z} b_{i}(\bar{z}) w(\bar{z}) I(\bar{z})
$$

where $b_{i}(\bar{z})$ is the balance at the average elevation of altitude interval $\Delta z$, determined from the least-squares equation for mass balance with altitude, and $w(\bar{z})$ and $I(\bar{z})$ are the width and length (in plan view) of that altitude interval about $\bar{z}$. The product of mass balance and area for each altitude interval was summed over the elevation range of each glacier. The altitude interval used was $50 \mathrm{~m}$.

The regression of mass balance with altitude, $b(\bar{z})$, was fitted to the summer and winter mass balances, and the error calculated using the 95\% confidence interval about the regression line. Average seasonal mass balances were calculated using Equation (4) and the errors carried through. The annual average mass balance was calculated as the sum of the seasonal average balances, and the error of the average annual value was calculated from the square root of the sum of the squared errors of the seasonal balances. To check the annual balance, it was also calculated using Equation (4). In all cases the annual balance from Equation (4) was within the error of the summed seasonal balances. The regression equation was not used directly for the annual balance because it typically did not equal the sum of the seasonal balances due to statistical variations in the data. The total mass balance of the glacier is calculated as the sum of the surface mass balance (Equation $(4) \times$ glacier area) and cliff balance, all expressed as volume (w.e.), divided by the area of the sub-horizontal glacier surface (Table 2).

Summer mass-balance values for Commonwealth and Howard Glaciers range from -32 to $+27 \mathrm{~mm}$ w.e., winter values range from -36 to $+51 \mathrm{~mm}$ w.e., and annual values range from -36 to $+52 \mathrm{~mm}$ w.e. Annual ablation from the ice cliffs accounts for up to $-2 \mathrm{~mm}$ w.e. of mass loss per year, well within the error of the mass-balance values. Given the small magnitude of the mass balance, a single snowfall or severe summer melt event can dominate the mass balance for that year. However, generally speaking, summer balances are negative and winter balances are positive. Correlations between annual and seasonal values showed that only winter balances were significantly correlated: $r^{2}$ of 0.56 and 0.82 for Commonwealth and Howard Glaciers, respectively. Plots of mass balance with time do not show any trends (Fig. 10). The sum of annual mass balance over the 8 years observed suggests that Commonwealth Glacier may be gaining mass ( $+72 \pm 80 \mathrm{~mm}$ w.e.), whereas Howard Glacier is in equilibrium $(+12 \pm 129 \mathrm{~mm}$ w.e.). Comparing 
Table 2. The seasonal and annual mass balance (w.e.) for the glaciers

\begin{tabular}{|c|c|c|c|c|c|c|c|c|}
\hline & \multicolumn{2}{|c|}{ Commonwealth } & \multicolumn{2}{|c|}{ Howard } & \multicolumn{2}{|c|}{ Canada } & \multicolumn{2}{|c|}{ Taylor } \\
\hline & $\begin{array}{c}\text { Balance } \\
\text { mm }\end{array}$ & $\begin{array}{l}\text { Error } \\
\pm \mathrm{mm}\end{array}$ & $\begin{array}{c}\text { Balance } \\
\text { mm }\end{array}$ & $\begin{array}{l}\text { Error } \\
\pm \mathrm{mm}\end{array}$ & $\begin{array}{c}\text { Balance } \\
\text { mm }\end{array}$ & $\begin{array}{l}\text { Error } \\
\pm \mathrm{mm}\end{array}$ & $\begin{array}{c}\text { Balance } \\
\text { mm }\end{array}$ & $\begin{array}{l}\text { Error } \\
\pm \mathrm{mm}\end{array}$ \\
\hline 1994 winter & 36 & 23 & 33 & 28 & -39 & 19 & & \\
\hline 1993/94 summer & -32 & 15 & -19 & 37 & -81 & 21 & & \\
\hline 1993/94 & 4 & 28 & 14 & 47 & -120 & 28 & & \\
\hline ELA & 964 m & & $813 \mathrm{~m}$ & & & & & \\
\hline 1995 winter & 51 & 26 & 37 & 44 & -58 & 40 & -79 & 27 \\
\hline 1994/95 summer & 1 & 14 & 5 & 47 & -51 & 33 & -54 & 30 \\
\hline 1994/95 & 52 & 30 & 42 & 64 & -109 & 52 & -133 & 40 \\
\hline ELA & $222 \mathrm{~m}$ & & $634 \mathrm{~m}$ & & & & & \\
\hline 1996 winter & -14 & 22 & -36 & 25 & -72 & 37 & -124 & 28 \\
\hline 1995/96 summer & -7 & 11 & 0 & 37 & -97 & 22 & -74 & 30 \\
\hline $1995 / 96$ & -21 & 25 & -36 & 44 & -169 & 43 & -198 & 41 \\
\hline ELA & 377 m & & $>1000 \mathrm{~m}$ & & & & & \\
\hline 1997 winter & 9 & 18 & 13 & 35 & -46 & 52 & -87 & 23 \\
\hline 1996/97 summer & 27 & 17 & 8 & 27 & -60 & 23 & -62 & 19 \\
\hline 1996/97 & 36 & 25 & 21 & 44 & -106 & 57 & -149 & 29 \\
\hline ELA & $298 \mathrm{~m}$ & & $423 \mathrm{~m}$ & & & & & \\
\hline 1998 winter & 41 & 31 & 12 & 50 & -52 & 36 & -75 & 30 \\
\hline 1997/98 summer & -10 & 9 & -8 & 22 & -83 & 19 & -97 & 26 \\
\hline $1997 / 98$ & 31 & 32 & 4 & 54 & -135 & 41 & -172 & 39 \\
\hline ELA & $296 \mathrm{~m}$ & & $822 \mathrm{~m}$ & & & & & \\
\hline 1999 winter & 5 & 18 & 29 & 35 & -84 & 26 & -79 & 27 \\
\hline 1998/99 summer & -21 & 27 & -14 & 22 & -91 & 17 & -83 & 15 \\
\hline 1998/99 & -16 & 33 & 15 & 41 & -175 & 31 & -162 & 31 \\
\hline ELA & 391 m & & $839 m$ & & & & & \\
\hline 2000 winter & 14 & 18 & -9 & 23 & -89 & 29 & -130 & 41 \\
\hline 1999/2000 summer & -24 & 23 & -24 & 21 & -87 & 16 & -105 & 20 \\
\hline 1999/2000 & -10 & 29 & -33 & 31 & -176 & 33 & -235 & 45 \\
\hline ELA & $429 m$ & & $970 m$ & & & & & \\
\hline 2000 winter & 2 & 22 & -14 & 26 & -69 & 15 & -105 & 33 \\
\hline 2000/01 summer & -6 & 10 & -1 & 13 & -54 & 21 & -73 & 16 \\
\hline $2000 / 01$ & -4 & 25 & -15 & 29 & -123 & 25 & -178 & 37 \\
\hline ELA & $273 \mathrm{~m}$ & & $893 \mathrm{~m}$ & & & & & \\
\hline
\end{tabular}

Notes: The balances for Canada and Taylor Glaciers apply only to the ablation zone. The ELA is given in meters above sea level.

year to year variability, the two glaciers generally mirror each other, though annual mass balances for Commonwealth Glacier tend to be more positive compared with Howard Glacier. This is generally reflected in the winter mass balance, which is more positive for Commonwealth Glacier. No such correlation exists for the summer balance. The ELA was quite different for each glacier (Table 2). For Howard Glacier the ELA averaged 799 ma.s.l. and for Commonwealth it averaged $406 \mathrm{~m}$ a.s.I. The standard deviations were 177 and 204 ma.s.l., respectively. The mass-balance variations of the ablation zones of Canada and Taylor glaciers are similar to those for Commonwealth and Howard Glaciers (not shown). For Taylor Glacier the mass-balance values are significantly more negative compared with the ablation zones of the other glaciers, especially during the winter.

\section{Glacier mass balance and climate}

Inspection of Figure 8 suggests a systematic change in massbalance values with position in Taylor Valley. At constant elevation, mass balance decreases with distance up-valley away from the coast. The trend in mass balance is explained by the valley climate trend. Travelling up-valley, away from the ocean, average wind speed and air temperature increase, which increases sublimation and melting. At the same time snowfall decreases (Fountain and others, 1999; Doran and others, 2002b), which decreases the mass input to the glaciers and decreases surface albedo. As summer air temperatures commonly hover just below freezing, net solar radiation is required to warm the ice to the melting temperature. The presence of snow reduces net radiation sufficiently to eliminate melt (Lewis and others, 1998). A trend surface of mass balance was statistically modeled using the average annual mass-balance values for four seasons with the most complete data (1994/95, 1995/96, $1999 / 2000,2000 / 01)$. We found a significant multiple linear regression $\left(r^{2}=0.80, p=0.03\right)$,

$$
\bar{b}_{i}=-0.16 d_{\mathrm{c}}+2.99 d_{\mathrm{f}}+15.25,
$$

where $\bar{b}_{i}$ is the average annual balance (mm w.e.) at stake $i$, $d_{c}$ is the distance $(\mathrm{km})$ from the coast up-valley and $d_{\mathrm{f}}$ is the 

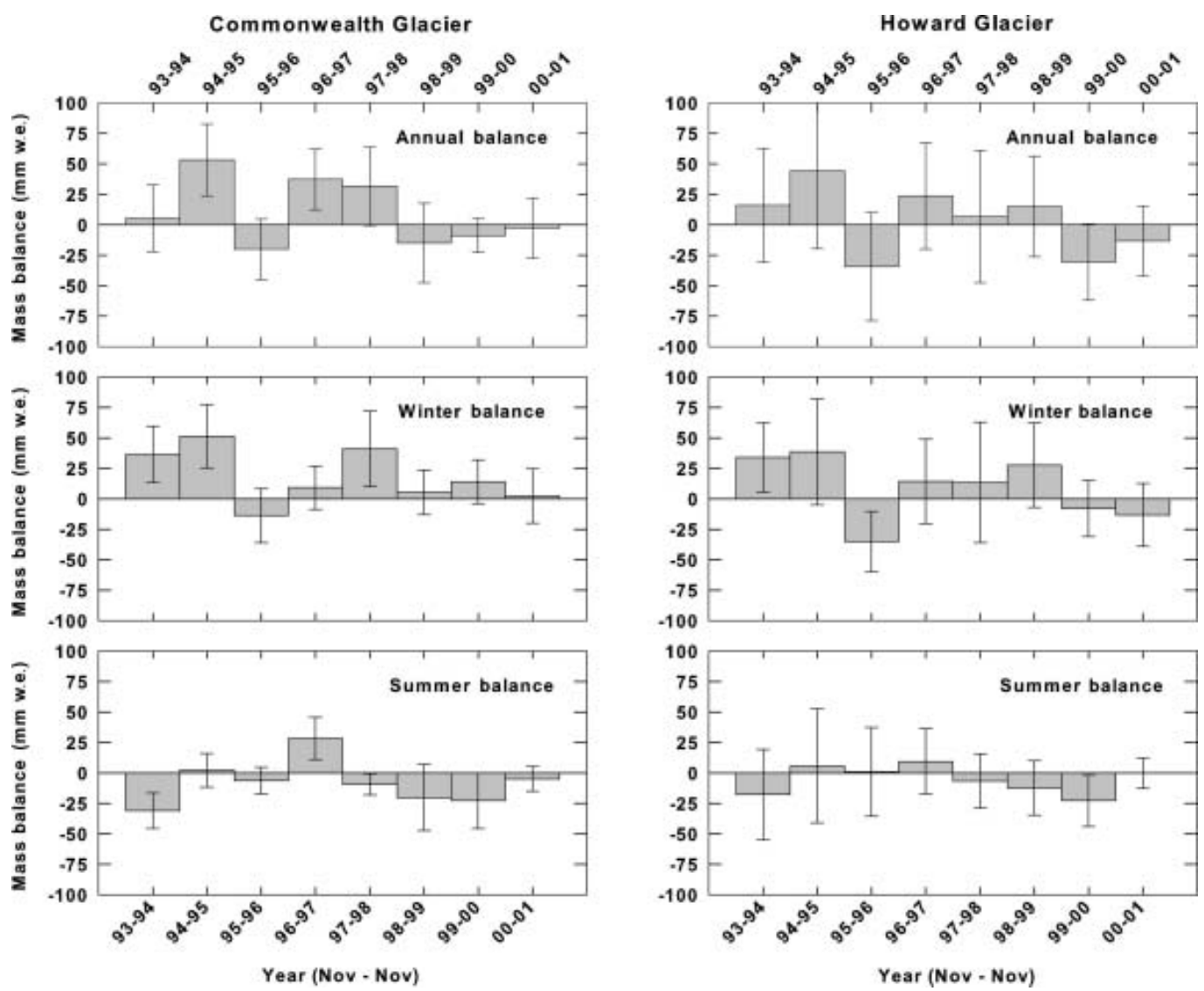

Fig. 10. Annual and seasonal mass-balance values for Commonwealth and Howard Glaciers.

distance $(\mathrm{km})$ from the center (talweg) of the valley bottom. The mass balance becomes increasingly negative with distance from the coast and increasingly positive with elevation, embodied in $d_{\mathrm{f}}$.

\section{GLACIER VELOCITY AND THICKNESS}

Glacier velocities and depths were measured at each massbalance pole to help define the geometry and dynamics of the glaciers. For displacement, the location of each pole was measured twice over the interval of a year using a Trimble 2480 global positioning system (GPS). The GPS unit was placed against the stake on the down-glacier side of the stake. In addition, the poles on Canada Glacier were surveyed (personal communication from E.D. Waddington 1996). The velocities range from 0.3 to $9.0 \mathrm{ma}^{-1}$ (Fig. 11). The horizontal velocity patterns are consistent with glacier topography. The horizontal velocities are higher where the glaciers are steeper and constricted by topographic features, such as Commonwealth Glacier where it flows from the accumulation to the ablation zone.

Ice depth was measured using an ice radar with a $2 \mathrm{MHz}$ frequency-centered pulse (Fountain and Jacobel, 1997). We measured the two-way travel time for the pulse to travel from the transmitter to the receiver and, correcting for the separation of antennae, estimated ice depth. Depth values were not migrated and we assume that the measured depth is found at the nadir between the antennae. Results (Fig. 11) show an overdeepening under the lower Taylor Glacier consistent with previous results (Robinson, 1984; Hubbard and others, 2004), suggesting that the glacier may be, or once was, wet-based. The thickness of
Commonwealth Glacier ranges from about 50 to $300 \mathrm{~m}$, Howard Glacier ranges from about 25 to $110 \mathrm{~m}$, and, within the ablation zone, Canada Glacier ranges from 25 to $206 \mathrm{~m}$.

\section{DISCUSSION AND CONCLUSIONS}

The mass balances of Commonwealth and Howard Glaciers indicate that they are in equilibrium with the current climate with no significant trends in the seasonal or annual mass balance. Annual mass-balance values range from about +60 to $-40 \mathrm{~mm}$, and for many years the results are not statistically different from zero. The seasonal values exhibit the same characteristics. Bull and Carnein (1970) showed that for Meserve Glacier in Wright Valley average mass balance from November 1965 to November 1966 was $-6 \mathrm{~mm}$. Annual and seasonal mass balance for 6 years from 1970 to 1975 of Jeremy Sykes, Alberich and Heimdall glaciers, also in Wright Valley, ranged from $+38 \mathrm{~mm}$ to $-44 \mathrm{~mm}$ (Chinn, 1980), consistent with the range we observed in Taylor Valley, and also with no observable trends. Seasonal mass-balance values are generally positive in winter and negative in summer; however, the reverse is not unusual. As annual snowfall is relatively small and snowfall occurs at all times of the year, a single large storm can cause either summer or winter to be the accumulation season. Correlations between seasonal and annual mass balances show that the winter season explains most of the variance in the annual values.

Unlike temperate glaciers, the accumulation zones of these polar glaciers generally gain mass in each season whereas the ablation zones lose mass each season. 
However, the accumulation of snow in the accumulation zone dominates the winter balance of the glacier, and the melt and sublimation in the ablation zone dominate the summer balance. Also, cliff ablation seems to be a special case for land-based polar glaciers, as most temperate glaciers do not form vertical cliffs around the glacier margin in the ablation zone. We found that annual cliff ablation accounted for a loss of up to $2 \mathrm{~mm}$ w.e. averaged over either Commonwealth or Howard Glacier, and calving accounted for $10 \%(0.2 \mathrm{~mm})$ of the cliff ablation. In comparison, from the data collected at Meserve Glacier (Bull and Carnein, 1970), we calculate that ice-cliff ablation accounted for a loss of $13 \mathrm{~mm}$ w.e. averaged over the glacier surface, and calving accounted for $27 \%(4 \mathrm{~mm})$ of the cliff ablation. Given the limited data and relatively short time-span of the measurements, both values may be correct. Calving processes remain enigmatic, although we suspect that the ice weakens and cracks due to thermal contraction and expansion, against a background of tensional forces parallel to the cliff face due to ice flow.

The average ELA for Commonwealth Glacier over the period of measurement, $406 \mathrm{~m}$ a.s.l., is close to the ELA, 375 ma.s.l., estimated from the inflection of contour lines (Fountain and others, 1999). According to Leonard and Fountain (2003), the observed ELA should be at a greater altitude than that determined from the inflection point. In contrast, the average ELA for Howard Glacier, 799 m a.s.I., is much higher than the 500 ma.s.l. estimated from the contour inflection. The uncertainty in the inflection point for Howard Glacier is much smaller than the approximately $300 \mathrm{~m}$ difference and may reflect differences between the instantaneous mass-balance measurements and the response time of approximately $10^{3}$ years (Fountain and others, 2004) required for these glaciers to adjust to new mass-balance conditions.

The spatial trend in climate within Taylor Valley exerts a strong control on spatial values of glacier mass balance. The valley becomes drier, warmer and windier inland, which reduces snowfall and increases sublimation, and becomes colder with more snow at higher elevations away from the valley bottom. This supports earlier work that identified a systematic change in ELA based on a change in meteorological variables (Fountain and others, 1999). That we can derive a simple multiple linear regression, based on distance from the coast and from the valley bottom, which accounts for $64 \%$ of the variance in mass-balance values, is surprising, but provides a sound basis for interpolating mass-balance values for unmeasured glaciers.

Results from our work and from previous studies in the McMurdo Dry Valleys show that the glaciers are effectively in equilibrium. This contrasts with trends of glacier shrinkage on the Antarctic peninsula (Scambos and others, 2000; Cook and others, 2005) and in the subpolar and temperate latitudes of the world (Dyurgerov and Meier, 2000). The equilibrium condition of the dry valley glaciers is a response to regional conditions. The dry valleys have cooled over the past few decades and this cooling appears to be part of a general trend in East Antarctica (Doran and others, 2002a). Thompson and Solomon (2002) identified a strengthening of the Antarctic Oscillation over the past few decades, which isolates the main part of the Antarctic continent from the warming temperatures in the lower latitudes while exposing the peninsula and sub-Antarctic islands to enhanced advection of warm air.
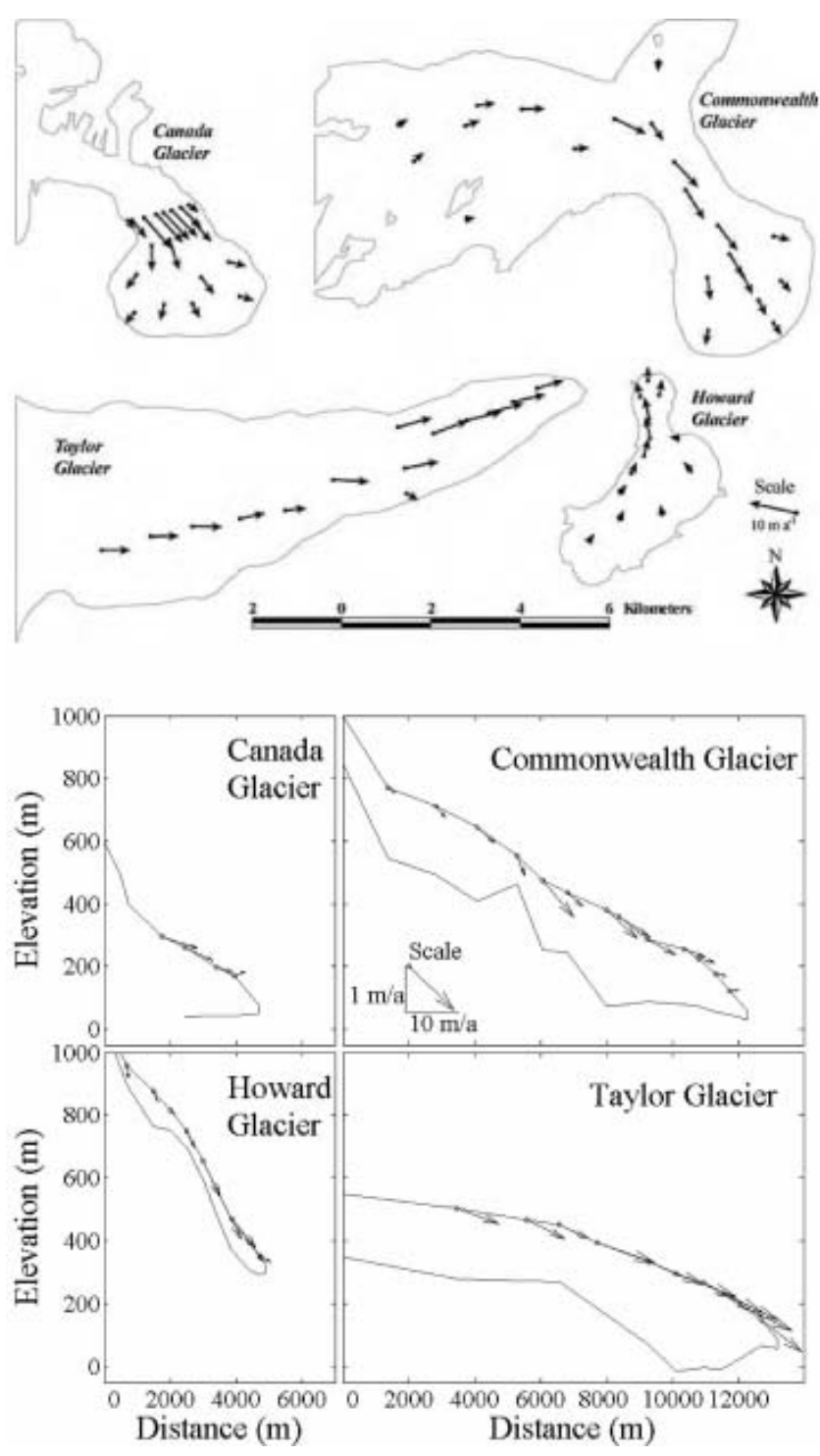

Fig. 11. Pattern of ice velocities on four glaciers in Taylor Valley, Antarctica. (a) Plan view pattern of velocities and (b) glacial crosssection along the longitudinal profile shown in Figure 6 . The bottom of the glacier is included in the bottom panels.

\section{ACKNOWLEDGEMENTS}

The mass-balance program has benefited from the efforts of many people. B. Vaughn helped with the set-up of the original network of poles. His efforts were followed by P. Langevin who spent several seasons in the valleys running the mass-balance program. Occasional volunteers included H. House and B. Davis, among others. We also received tremendous support from the Field Safety team at Raytheon Polar Services, including B. Brenner, S. Dunbar, W. McCormick and many others. They provided field help in the accumulation zones of the glaciers and occasionally elsewhere on the ice. In addition, B. Johns, K. Faux, S. O'Neil, and S. Reeder of UNAVCO provided great assistance with the GPS of the poles, and help with the mass-balance measurements. We appreciate the support of our fellow Long-Term Ecological Research (LTER) group members and the camp management of R. Spain and P. Adkins. This work was supported by US National Science Foundation (NSF) grants OPP 9211773, 9813061, 9810219, 0096450 and ANT-0423595. 


\section{REFERENCES}

Andreassen, L.M. 1999. Comparing traditional mass balance measurements with long-term volume change extracted from topographical maps: a case study of Storbreen glacier in Jotunheimen, Norway, for the period 1940-1997. Geogr. Ann., 81A(4), 467-476.

BioScience. 1999. [Special section on the McMurdo Dry Valleys.] BioScience, 49(12), 959-1017.

Brandt, R.E. and S.G. Warren. 1993. Solar-heating rates and temperature profiles in Antarctic snow and ice. J. Glaciol., 39(131), 99-110.

Bromley, A.M. 1985. Weather observations, Wright Valley, Antarctica. Wellington, New Zealand Meteorological Service. (Information Publication 11.)

Bull, C. and R. Carnein. 1970. The mass balance of a cold glacier: Meserve Glacier, south Victoria Land, Antarctica. IASH Publ. 86 (Symposium at Hanover 1968 - Antarctic Glaciological Exploration (ISAGE)), 429-446.

Chinn, T.J. 1980. Glacier balances in the Dry Valleys area, Victoria Land, Antarctica. IAHS Publ. 126 (Riederalp Workshop 1978 World Glacier Inventory), 237-247.

Chinn, T.J.H. 1981. Hydrology and climate of the Ross Sea area. J. R. Soc. New Zeal., 11(4), 373-386.

Chinn, T.J.H. 1985. Structure and equilibrium of the Dry Valleys glaciers. NZ Antarct. Rec., 6, 73-88.

Chinn, T.J.H. 1991. Polar glacier margin and debris features. Mem. Soc. Geol. Ital., 46, 25-44.

Chinn, T.J. 1998. Recent fluctuations of the Dry Valleys glaciers, McMurdo Sound, Antarctica. Ann. Glaciol., 27, 119-124.

Clow, G.D., C.P. McKay, G.M. Simmons, Jr and R.A. Wharton, Jr. 1988. Climatological observations and predicted sublimation rates at Lake Hoare, Antarctica. J. Climate, 1(7), 715-728.

Cook, A.J., A.J. Fox, D.G. Vaughan and J.G. Ferrigno. 2005. Retreating glacier fronts on the Antarctic Peninsula over the past half-century. Science, 308(5721), 541-544.

Denton, G.H., J.G. Bockheim, S.C. Wilson and M. Stuiver. 1989. Late Wisconsin and Early Holocene glacial history, inner Ross embayment, Antarctica. Quat. Res., 31(2), 151-182.

Doran, P.T. and 12 others. 2002a. Antarctic climate cooling and terrestrial ecosystem response. Nature, 415(6871), 517-520.

Doran, P.T. and 6 others. 2002b. Climate observations from the McMurdo Dry Valleys, Antarctica, 1986-2000. J. Geophys. Res., 107(D24), 4772. (10.1029/2001JD002045.)

Dyurgerov, M.B. and M.F. Meier. 2000. Twentieth century climate change: evidence from small glaciers. Proc. Natl. Acad. Sci. USA (PNAS), 97(4), 1406-1411.

Dyurgerov, M., Meier, M. and R. Armstrong, eds. 2002. Glacier mass balance and regime: data of measurements and analysis. Boulder, CO, University of Colorado. Institute of Arctic and Alpine Research. (INSTAAR Occasional Paper 55.)

Fountain, A.G. and R.W. Jacobel. 1997. Advances in ice radar studies of a temperate alpine glacier, South Cascade Glacier, Washington, U.S.A. Ann. Glaciol., 24, 303-308.

Fountain, A.G. and A. Vecchia. 1999. How many stakes are required to measure the mass balance of a glacier? Geogr. Ann., 81A $(4), 563-573$

Fountain, A.G., G.L. Dana, K.J. Lewis, B.H. Vaughn and D.M. McKnight. 1998. Glaciers of the McMurdo Dry Valleys, southern Victoria Land, Antarctica. In Priscu, J.C., ed. Ecosystem dynamics in a polar desert: the McMurdo Dry Valleys,
Antarctica. Washington, DC, American Geophysical Union, 65-75. (Antarctic Research Series 72.)

Fountain, A.G., K.J. Lewis and P.T. Doran. 1999. Spatial climatic variation and its control on glacier equilibrium line altitude in Taylor Valley, Antarctica. Global Planet. Change, 22(1-4), $1-10$

Fountain, A.G., T.A. Neumann, P.L. Glenn and T. Chinn. 2004. Can climate warming induce glacier advance in Taylor Valley, Antarctica? J. Glaciol., 50(171), 556-564.

Grove, A.T. 2001. The 'Little Ice Age' and its geomorphological consequences in Mediterranean Europe. Climatic Change, 48(1), 121-136.

Hall, B.L., G.H. Denton, D.R. Lux and C. Schluchter. 1997. Pliocene paleoenvironment and Antarctic ice sheet behavior: evidence from Wright Valley. J. Geol., 105(3), 285-294.

Holmlund, P. and P. Jansson. 1999. The Tarfala mass balance programme. Geogr. Ann., 81A(4), 621-631.

Hubbard, A., W. Lawson, B. Anderson, B. Hubbard and H. Blatter. 2004. Evidence for subglacial ponding across Taylor Glacier, Dry Valleys, Antarctica. Ann. Glaciol., 39, 79-84.

Leonard, K.C. and A.G. Fountain. 2003. Map-based methods for estimating glacier equilibrium-line altitudes. J. Glaciol., 49(166), 329-336.

Lewis, K.J., A.G. Fountain and G.L. Dana. 1998. Surface energy balance and meltwater production for a Dry Valley glacier, Taylor Valley, Antarctica. Ann. Glaciol., 27, 603-609.

Liston, G.E., J.G. Winther, O. Bruland, H. Elvehøy and K. Sand. 1999. Below-surface ice melt on the coastal Antarctic ice sheet. J. Glaciol., 45(150), 273-285.

Lliboutry, L. 1974. Multivariate statistical analysis of glacier annual balances. J. Glaciol., 13(69), 371-392.

Meier, M.F. and W.V. Tangborn. 1965. Net budget and flow of South Cascade Glacier, Washington. J. Glaciol., 5(41), 547-566.

Nylen, T.H., A.G. Fountain and P.T. Doran. 2004. Climatology of katabatic winds in the McMurdo Dry Valleys, southern Victoria Land, Antarctica. J. Geophys. Res., 109(D3), D03114. (10.1029/ 2003JD003937.)

Péwé, T.L. and R.E. Church. 1962. Glacier regimen in Antarctica as reflected by glacier-margin fluctuation in historic time with special reference to McMurdo Sound. IASH Publ. 58 (Symposium at Obergurgl 1962 - Variations of the Regime of Existing Glaciers), 295-305.

Post, A., D. Richardson, W.V. Tangborn and F.L. Rosselot. 1971. Inventory of glaciers in the North Cascades, Washington. USGS Prof. Pap. 705-A.

Robinson, P.H. 1984. Ice dynamics and thermal regime of Taylor Glacier, South Victoria Land, Anatarctica. J. Glaciol., 30(105), 153-160.

Scambos, T.A., C. Hulbe, M. Fahnestock and J. Bohlander. 2000. The link between climate warming and break-up of ice shelves in the Antarctic Peninsula. J. Glaciol., 46(154), 516-530

Taylor, G. 1916. With Scott: the silver lining. London, Smith, Elder and Co.

Thompson D.W.J and S. Solomon. 2002. Interpretation of recent Southern Hemisphere climate change. Science, 296(5569), 895-899.

Wilch, T.I., D.R. Lux, G.H. Denton and W.C. McIntosh. 1993. Minimal Pliocene-Pleistocene uplift of the dry valleys sector of the Transantarctic Mountains: a key parameter in ice-sheet reconstructions. Geology, 21(9), 841-844. 